Pesq. Vet. Bras. 37(3):234-240, março 2017

DOI: $10.1590 / \mathrm{S} 0100-736 \mathrm{X} 2017000300006$

Topic of General Interest

\title{
Brucellosis in water buffaloes ${ }^{1}$
}

\author{
Melina G.S. Sousa ${ }^{2}$, Felipe M. Salvarani², Henrique A. Bomjardim² ${ }^{2}$, Marilene F. Brito ${ }^{3}$ \\ and José D. Barbosa ${ }^{2 *}$
}

\begin{abstract}
Sousa M.G.S., Salvarani F.M., Bomjardim H.A., Brito M.F. \& Barbosa J.D. 2017. Brucellosis in water buffaloes. Pesquisa Veterinária Brasileira 37(3):234-240. Instituto de Medicina Veterinária, Faculdade de Medicina Veterinária, Universidade Federal do Pará, Campus de Castanhal, Rodovia BR-316 Km 61, Castanhal, PA 68741-740, Brazil. E-mail: diomedes@ufpa.br

The domestication of water buffaloes (Bubalus bubalis) originated in India and China and spread throughout the world and represents an important source of food of high biological value. Given the importance and relevance of brucellosis for buffalo production, this article reviews the history, etiopathogenesis, epidemiology, clinical signs, anatomopathological findings, diagnosis and control of the disease, focusing on data from studies on water buffaloes performed in different countries and the Brazilian Amazon biome.
\end{abstract}

INDEX TERMS: Brucellosis, water buffaloes, Bubalus bubalis, Brucella abortus, diagnosis, control, zoonosis.

RESUMO.- [Brucelose em bubalinos.] A domesticação do búfalo (Bubalus bubalis) ocorreu particularmente na Índia e China, difundindo-se pelo mundo, gerando fontes de alimento de alto valor biológico. Diante da importância e relevância da brucelose para a bubalinocultura este trabalho tem por objetivo fazer uma revisão acerca do histórico da doença, etiopatogenia, fatores epidemiológicos, sinais clínicos, achados anatomopatológicos, diagnóstico e o controle, com enfoque nos dados obtidos em estudos em bubalinos no mundo e no Bioma Amazônico brasileiro.

TERMOS DE INDEXAÇÃO: Brucelose, búfalos, Bubalus bubalis, Brucella abortus, aborto, diagnóstico, controle, zoonose.

\section{INTRODUCTION}

Water buffalo (Bubalus bubalis) domestication occurred between 2500 and $1400 \mathrm{BC}$, particularly in India and China. Since then, water buffalo production has spread throughout the world, generating an important source of food of high biological value, such as milk and meat, and

\footnotetext{
${ }^{1}$ Received on November 4, 2016.

Accepted for publication on November 22, 2016.

${ }^{2}$ Instituto de Medicina Veterinária, Faculdade de Medicina Veterinária, Universidade Federal do Pará (UFPA), Campus de Castanhal, Rodovia BR-316 Km 61, Castanhal, PA 68741-740, Brazil. *Corresponding author: diomedes@ufpa.br

${ }^{3}$ Departamento de Epidemiologia e Saúde Pública, Instituto de Veterinária (IV), Universidade Federal Rural do Rio de Janeiro (UFRRJ), BR-465 Km 7, Seropédica, RJ 23890-000, Brazil.
}

animal labor, especially for individuals from poor and developing countries (Cockrill 1984). The water buffalo was introduced in Brazil in 1895 on the island of Marajó, Pará. Currently, according to the genealogical record of the Brazilian Association of Buffalo Breeders (Associação Brasileira de Criadores de Búfalos - ABCB), the following breeds are present in Brazil: Mediterranean, Murrah, Jafarabadi and Carabao, and Baio (ABCB 2015).

The world buffalo population exceeds 168 million animals, geographically distributed in the following proportions: 161 million (95.83\%) in Asia, 3.717 million (2.24\%) in Africa, 3.3 million (1.96\%) in South America, with a large herd in Brazil, 500,000 (0.30\%) in Europe, and 40,000 (0.02\%) in Australia (Borghese 2005). Brazil has approximately 1,319,478 water buffaloes, and the North region, which has 877,345 animals, is the largest producer in the country, especially the state of Pará, which accounts for $37.4 \%(493,646)$ of the national herd (IBGE 2014).

Brucellosis, a zoonotic disease of chronic evolution and granulomatous character, is one of the infectious contagious diseases that affect water buffaloes; it is caused by facultative intracellular bacteria of the genus Brucella that infects cells of the mononuclear phagocyte system (Cheville et al. 1993, Xavier et al. 2009). The main etiological agent for water buffaloes is Brucella abortus biovar 1 (Fosgate et al. 2002, Megid et al. 2005). This disease has caused major economic losses due to reproductive problems, such as reduced fertility, birth of weak calves, and abortion (Corbel 1997). Brucellosis is also associated 
with fibrinous suppurative necrotic placentitis (Sousa et al. 2015a).

Brucellosis has been diagnosed in water buffaloes from Egypt (Gentile 1957, Menshawy et al. 2014), Italy (Guarino et al. 2001), Trinidad and Tobago (Fosgate et al. 2002), Pakistan (Nasir et al. 2004), Argentina (Konrad et al. 2013) and Brazil (Ogassawara et al. 1969, Santa Rosa et al. 1969, Láu \& Singh 1985, Bastianetto et al. 2005, Silva et al. 2014a, Sousa et al. 2015a, 2015b).

Given the importance of brucellosis in buffalo production, this article reviews the history, etiopathogenesis, epidemiology, clinical signs, anatomopathological findings, diagnosis and control of the disease, focusing on data from studies on water buffaloes performed in the Brazilian Amazon biome.

\section{HISTORY OF BRUCELLOSIS}

In 1751, Cleghorn, a British army surgeon serving in Minorca Island, Spain, described cases of a disease with symptoms similar to those described by Hippocrates in 460 BC. However, it was Marston, also a British army surgeon, who in 1859 characterized the disease as an independent disease entity after he acquired brucellosis on the Island of Malta, located south of Sicily, Italy, and reported for the first time "recurrent gastric fever" as its main symptom (Evans 1950).

On July 9, 1887, the British army physician David Bruce, who was also on the Island of Malta during the Napoleonic wars, isolated the specific agent responsible for the disease known as Malta fever (or Mediterranean fever or undulant fever) from the spleen of a sick person. He then found the cause of the disease by isolating the etiological agent from splenic cultures of seven fatal cases and by experiments with animals. In 1893, Bruce named the microorganism Micrococcus melitensis, a reference to the Roman name for Malta, Melite (Isle of Honey). In 1905, Zammit successfully demonstrated that the Maltese goat is an animal host of M. melitensis by finding that sera from goats reacted experimentally with the antigen of Malta fever via an agglutination test and via isolation of $M$. melitensis in pure culture from the animal's blood. Later, Horrocks confirmed that M. melitensis was also present in the milk of infected goats. In 1906, Birt and Strachan reported that they had found Malta fever in South Africa and blamed goat milk, which had been widely consumed in the affected region; they confirmed the presence of Malta fever in South Africa in 1909. During his work in Uganda in 1909, Bruce investigated Muhinyo disease, showing that it was also Malta fever. The disease was also reported in Gibraltar, in the Orange River British Colony, in the Blue Nile in Africa and in Sudan (Vassallo 1992).

In 1914, Crawford Kennedy suggested the possibility of an infection by $M$. melitensis in cows in England, showing that the milk and serum of apparently healthy animals agglutinated with the antigen of $M$. melitensis. Subsequent studies, especially after World War I, explained the relationship between contagious abortion in cattle and Malta fever, with the understanding that the causative organism, named Bacillus abortus, isolated in December 1895 by Dr. Bernhard Bang, was actually a distinct strain of $M$. melitensis (Vassallo 1992).

In 1918, the physician Alice Evans identified brucellosis for the first time in humans in the United States, stating that there was a close relationship between B. abortus and M. melitensis, concluding that the bacteria isolated from goats, cattle and humans were similar and that M. melitensis was a bacillus and not a coccus as originally described. She also suggested that the disease should be called brucellosis, in reference to Colonel David Bruce. Two years later, Meyer and Shaw proposed the genus Brucella (Pacheco \& Mello 1956). In 1938, an editorial by Colonel William Horrocks analyzed the results of epidemiological investigations in France and described the differences between the strains of $B$. abortus, B. melitensis and B. suis responsible for undulant fever in cattle, goats and pigs, respectively (Vassallo 1992).

The first report of isolation of Brucella in buffaloes occurred in 1948 in Cairo, Egypt, from milk samples from sick buffalo cows (Gentile 1957). According to the literature, B. abortus infection in buffaloes has been detected in Italy by indirect enzyme-linked immunoassay (ELISA) (Guarino et al. 2001), in Trinidad and Tobago by serology and bacterial culture (Fosgate et al. 2002, Fosgate et al., 2011), in Pakistan in private livestock farms (Nasir et al. 2004), and in Argentina by fluorescence polarization assay (FPA) (Konrad et al. 2013). In Egypt, a recent study showed the presence of $B$. suis and B. abortus in domestic ruminants, including buffaloes, using polymerase chain reaction (PCR) (Menshawy et al. 2014).

In 1895, water buffaloes were introduced in Brazil via the island of Marajó; the buffaloes were imported from Australia, Egypt, India, Italy and Southeast Asian countries. On the island of Marajó, the animals found optimal breeding conditions. In the following decades, water buffaloes were introduced into other regions of Brazil, mainly in places with a hot and humid climate (Jorge 2005). The first report of brucellosis in buffaloes in Brazil was in $1969 ; 40.9 \%(27 / 66)$ of the animals investigated were seropositive according to the rapid agglutination test (RAT) in plates (Santa Rosa et al. 1969). However, the etiological agent was first isolated in adult buffalo cows in Brazil by Ogassawara et al. (1969) from joint hygroma. Later, seroepidemiological surveys demonstrated the presence of brucellosis in buffaloes in different Brazilian states (Láu \& Singh 1985, Bastianetto et al. 2005, Silva et al. 2014a). In 2015, a study that evaluated buffalo cows with brucellosis from the Amazon biome detected, by real-time PCR (qPCR) and for the first time in the world, $B$. abortus starting in the second month of pregnancy in the amniotic fluid, allantoic fluid and uterus of buffalo cows and starting in the fifth month of pregnancy in fetal tissues (Sousa et al. 2015a).

\section{ETIOLOGY OF BRUCELLOSIS}

Brucellosis is an infectious contagious disease usually of chronic evolution and granulomatous character, caused by facultative intracellular bacteria of the genus Brucella (Fosgate et al. 2002). Brucella spp. are gram-negative coccobacilli, aerobic or microaerophilic, non-motile, lacking capsules and non-spore forming. They have oxidative metabolism based on nitrate reduction. In biochemical tests, Brucella spp. are classified as catalase and oxidase positive microorganisms, non-lactose fermenters, urease positive and indole negative (Nielsen et al. 2004).

The species can be divided in two distinct antigenic groups according to the presence or absence of the 0 surface antigen: the smooth or classical species, Brucella abortus, B. melitensis, B. suis, and B. neotomae, and the rough species, B. ovis and B. canis. Each species has a preferred host: $B$. abortus is the main etiological agent of brucellosis in cattle and buffaloes, $B$. melitensis affects sheep and goats and causes severe infections in humans (Osterman \& Moriyon 2006), B. suis mainly affects pigs (Huddleson 1931), $B$. neotomae was isolated from wild rodents of the species Neotoma lepida (Stoenner \& Lackman 1957), B. ovis is res- 
ponsible for epididymitis in sheep (Buddle 1956), and $B$. canis is responsible for canine brucellosis (Carmichael \& Bruner 1968).

Some species are subdivided into biovars. There are seven biovars for $B$. abortus $(1,2,3,4,5,6$ and 9), three for $B$. melitensis (1, 2 and 3$)$ and five for $B$. suis $(1,2,3,4$ and 5$)$ (Moreno et al. 2002). B. abortus biovar 1 has been reported in buffaloes in India (Renukaradhya et al. 2002), Italy (FAO/WHO 1986, Di Giannatale et al. 2008, Borriello et al. 2013, Garofolo et al. 2015) and Trinidad and Tobago (Fosgate et al. 2002). B. abortus biovar 3 has been isolated in the eastern Mediterranean (FAO/WHO 1986) and Italy (Di Giannatale et al. 2008, Borriello et al. 2013), while biovar 6 was isolated from buffaloes in Italy, in addition to B. melitensis biovar 3 (Di Giannatale et al. 2008). In Brazil, the first report of $B$. abortus biovar 1 in buffaloes was described by Megid et al. (2005) in an aborted fetus at approximately seven months of gestation. Recently, B. abortus biovar 5 was isolated in Argentina from an aborted buffalo fetus, constituting the first report of this biovar in water buffaloes (Martínez et al. 2014).

Some species of Brucella were recently described as those isolated from cetaceans and seals, B. ceti and B. pinnipedialis, respectively (Foster et al. 2007). B. microti was isolated from the rodent Microtus arvalis (Scholz et al. 2008) and the fox Vulpes (Scholz et al. 2009), and B. inopinata was isolated from humans, but the preferred animal reservoir has not been identified (Scholz et al. 2010). In 2014, B. papionis was isolated from primates, Papio spp. (Whatmore et al. 2014).

\section{EPIDEMIOLOGICAL FACTORS}

Brucellosis has worldwide distribution, but it has been eradicated in some countries of Europe and North America, which created restrictions on the international trade of live animals and animal by-products to these regions (Garcia-Carrillo 1990, FAO 1997). In contrast, in some countries such as Pakistan, seropositive buffaloes are highly prevalent, and producers face major challenges in containing the spread of the disease because young animals are routinely introduced into properties without undergoing diagnostic tests (Nasir et al. 2004). Italy has its own particular epidemiological situation, represented by infected buffaloes mainly in the Campania region, which has $73 \%$ of the country's buffalo population (Di Giannatale et al. 2008). Despite the implementation of eradication measures, the epidemiological situation of brucellosis in buffaloes in Italy, especially in the province of Caserta, is still problematic (Caporale et al. 2010). In northeast Argentina, Konrad et al. (2013) reported $6.4 \%$ positive buffaloes by FPA.

In Brazil, the prevalence of brucellosis in buffalo herds has been studied since the 1970s, when Costa et al. (1973) evaluated 199 serum samples by RAT and found that $20.6 \%$ of the animals were positive. In the state of Goiás, Sandoval et al. (1979) evaluated 992 serum samples and found that $4.33 \%$ and $5.69 \%$ of the animals were positive by RAT and the rose bengal plate test (RBPT), respectively. In the state of São Paulo, Mathias et al. (1998) tested 462 animals from
16 herds located in seven municipalities by complement fixation test (CFT) and found $10.39 \%$ positivity, in the Ribeira Valley region, also in the state of São Paulo. Bastianetto et al. (2005) reported the occurrence of brucellosis in adult females, ranging from zero to $37.5 \%$ by RBPT, slow agglutination test (SAT) and 2-mercaptoethanol test (2-ME), in the Upper São Francisco region of Minas Gerais. Chaves et al. (2012) reported 5.18\% occurrence of brucellosis in buffaloes by RBPT, SAT and 2-ME, in the state of Maranhão. Recently, in North Brazil, the region with the largest buffalo herd in the country, Silva et al. (2014a) reported 3.67\% (176/4796) positivity using 2-ME. Still in the North region, specifically the state of Pará, Silva et al. (2014b) evaluated 3,917 serum samples from pregnant and non-pregnant buffalo cows, of which 2,809 samples were from the island of Marajó and 1,108 from the mainland, and found that 4.8\% (188/3.917) of the animals were seropositive by RBPT. Of these, $95.7 \%$ (180/188) were confirmed by 2-ME, showing that the infection is active in the Brazilian region that has the largest buffalo population and that the disease poses a risk to public health and buffalo production in the Amazon biome.

The epidemiology of Brucella infection has not been extensively studied in buffaloes; however, calves born from seropositive buffalo cows in an infected herd are more likely to become seropositive compared to calves born from seronegative cows (Akhtar \& Mirza 1995). In addition, keeping a large number of animals in a small area facilitates the transmission of the disease, which may be an important factor for the spread of the disease (Polding 1947). Some behavioral characteristics of buffaloes, for example, staying for long periods in mud holes and weirs, facilitates exposure to certain microorganisms, such as Brucella, which is able to survive for weeks or months in water, urine, feces, moist soil, and manure under favorable humidity and temperature conditions (Wray 1975, Borriello et al. 2013).

The main infection route of brucellosis is the digestive system due to the direct contact with placental remains, fetal adnexa or aborted fetuses (Ackermann et al. 1988). Recently, the relevance of intrauterine transmission in the epidemiological chain of brucellosis in buffaloes was characterized by the detection of Brucella abortus in the amniotic fluid, allantoic fluid and uterus of buffalo cows starting in the second month of pregnancy and in the fetal tissues starting in the fifth month of pregnancy (Sousa et al. 2015a). Other infection routes include ingestion of contaminated milk (Wilesmith 1978, Nicoletti 1980) and artificial insemination with contaminated semen (Rankin 1965).

An experimental study of intraconjunctival inoculation of a strain of Brucella abortus 1969D suggests that buffaloes are more resistant to $B$. abortus infection than cattle (Adesiyun et al. 2010). However, a study conducted in Trinidad and Tobago demonstrated that $B$. abortus strains isolated from buffaloes are less virulent than those isolated from cattle. Therefore, in addition to apparently being more resistant to infection, buffaloes tend to be infected with less virulent strains (Adesiyun et al. 2011). 


\section{PATHOGENESIS OF BRUCELLOSIS}

The infection starts mainly in the oral, nasopharyngeal and conjunctival mucosa or in broken skin. After contamination, the bacteria are phagocytosed primarily by macrophages and transported to regional lymph nodes, where, as facultative intracellular microorganisms, they multiply inside the cells, particularly cells of the mononuclear phagocyte system, and may evade the immune response for weeks to months, causing inflammatory and anatomopathological changes, such as hyperplasia and lymphadenitis (Carvalho Neta et al. 2010, Sousa et al. 2015b).

From the regional lymph nodes, the bacteria can disseminate intracellularly in macrophages or extracellularly, through the hematogenous or lymphatic routes, spreading to other lymph nodes, especially in the mammary glands and organs rich in phagocytic mononuclear cells (Harmon et al. 1988, Xavier et al. 2009, Sousa et al. 2015b). The predilection sites of the Brucella genus are those that offer substances necessary to their metabolism, such as erythritol, present in the pregnant uterus, mammary and osteoarticular tissues and the organs of the male reproductive system. Infection of a pregnant uterus occurs by the hematogenous route, and changes vary with infection intensity and time of pregnancy. The bacteria have a strong tropism for the uterus with high affinity for trophoblasts, especially during the last trimester of gestation, due to high concentrations of erythritol and steroid hormones, favoring bacterial survival because the products of erythritol degradation are used by Brucella abortus as an energy source (Samartino \& Enright 1996, Xavier et al. 2009).

\section{CLINICAL SIGNS}

The clinical signs of brucellosis are related to the reproductive age of the animals, immune status, infection routes and virulence of the Brucella strain. The disease mainly affects the reproductive and osteoarticular systems, causing reduced fertility in males and females and birth of weak calves and often causing abortion in the last trimester of gestation (Mohan 1968, Enright 1990, Xavier et al. 2009). Brucellosis can also decrease milk production and increase the number of somatic cells in milk (Meador \& Deyoe 1989).

The inflammatory process causes necrotic-inflammatory lesions in the placenta and lysis of the placental villi, resulting in detached cotyledons impairing maternal-fetal circulation, hindering the transport of nutrients and oxygen to the fetus and leading to birth of weak calves or abortion (Xavier et al. 2009, Sousa et al. 2015a). After the first abortion, due to the development of cellular immunity, there is a significant decrease in the number and size of lesions in placentomes in subsequent pregnancies. Therefore, abortions are less frequent, but other clinical manifestations develop, such as retained placenta, stillbirth or birth of weak calves, as well as metritis or chronic endometritis and, consequently, subfertility, infertility or sterility (Xavier et al. 2009).

\section{ANATOMOPATHOLOGICAL FINDINGS}

In buffaloes, macroscopic lesions are characterized by placentitis with a brownish exudate and fetid odor, are- as of necrosis and fibrin, and congestion and multifocal hemorrhages. Uteri have necrotic foci, placentomes with fibrinopurulent exudate with fetid odor, edema and intercotyledonary chorioallantoic hemorrhage, caruncles with multifocal fibrinopurulent exudate and/or congestion and hemorrhagic areas (Sousa et al. 2015a).

The microscopic findings of brucellosis in buffaloes are placentitis characterized by the presence of necrotic foci and dense inflammatory infiltrate by polymorphonuclear cells, congestion, hemorrhage and areas with fibrin exudation, as well as inflammatory infiltrate with lymphocytes, plasma cells and microgranulomas with some neutrophils, and invasion and multiplication of numerous basophilic coccoid bacterial colonies in placental trophoblasts. Chronic suppurative endometritis with areas of fibrosis and the presence of numerous basophilic coccoid bacterial colonies on the endometrial ulcerated surface is also observed. In the lymph nodes, congestion, edema, fibrin, infiltration by neutrophils, histiocytes and plasma cells are observed, which characterize regional lymphadenitis (Sousa et al. 2015b). In buffalo fetuses, liver with small foci of lymphocytic infiltrates distributed throughout the parenchyma, with mild to moderate injury, diffuse vacuolization of hepatocytes, kidney and spleen congestion, congestion, edema and fibrin in the lymph nodes are detected (Sousa et al. 2015a).

\section{DIAGNOSIS}

The diagnosis of brucellosis can be performed by direct and indirect methods. Serological tests, an indirect method, focusing on the detection of anti-Brucella spp. antibodies are a good choice due to the low cost, convenience and speed. In Brazil, the methods recommended by the Ministry of Agriculture, Livestock and Food Supply (Ministério da Agricultura, Pecuária e Abastecimento - MAPA) for diagnosis of brucellosis in buffaloes are the same recommended for cattle, namely, the milk ring test (MRT) and the RBPT, used as screening tests, and the 2-ME and the CFT, as confirmatory tests (Brasil 2006).

However, the literature cites a number of other serological tests that can be used for the diagnosis of brucellosis, such as the FPA (Nielsen et al. 2001, Paulin et al. 2012), competitive ELISA (Paulin et al. 2012) and ELISA with a Protein-G-based indicator system (Kumar \& Chand 2011). Of these, the most promising is the competitive ELISA (Mathias et al. 1998, Molnár et al. 2002, Paulin et al. 2012) and the FPA (Montagnaro et al. 2008, Paulin et al. 2012). Dot-Blot assays and CFT are also efficient for detecting significant titers in buffaloes vaccinated with two doses of RB51, being an alternative in serological surveillance for early detection of infected animals (Ramnanan et al. 2012).

The direct methods of diagnosis of brucellosis can be performed by bacterial isolation and detection of nucleic acids by molecular biology. A test that has shown promising results for brucellosis diagnosis is qPCR because of its high levels of sensitivity and specificity (Hinić et al. 2009, Caitano et al. 2014). Moreover, it has been a promising alternative for the direct diagnosis of slow growing organisms because of its ability to detect small amounts of DNA in the sample regardless of its viability (Erlich et al. 1991, Al Dahouk et al. 2003). 


\section{CONTROL}

Control of brucellosis in buffaloes in the Amazon biome and throughout Brazil has relied on vaccination of three- to eight-month-old females with the Brucella abortus vaccine strain B19, laboratory tests prior to animal transportation for breeding and elimination of positive animals as recommended by the National Program for Control and Eradication of Brucellosis and Tuberculosis (Programa Nacional de Controle e Erradicação da Brucelose e Tuberculose - PNCEBT). The program does not distinguish between cattle and buffaloes (Brasil 2006).

The B19 vaccine is a live attenuated vaccine, of low cost and capable of inducing long lasting immunity; however, the persistence of the vaccine antibodies depends mainly on the age of the animals at the time of vaccination (Sellem et al. 2010). The B19 vaccine is the most widely used worldwide and is being used for the control of brucellosis in several countries that have succeeded in reducing the prevalence of the disease or have eradicated it. It has been used in cattle and buffaloes since 1930, with satisfactory results, as it is an effective tool in the prevention of brucellosis (Crasta et al., 2008). B19 is a smooth Brucella strain; therefore, the vaccinated animals develop antibodies that cannot be differentiated from those produced during $B$. abortus infection by the serological tests routinely used. The persistence of the antibodies depends on the age of the animal, vaccination route and dosage (Nicoletti 1990).

Jamal et al. (2003) reported that the antibody titers of three- to eight-month-old buffalo cows vaccinated with the B. abortus B19 vaccine strain became zero 91 days post-vaccination, as measured by the serum agglutination test and 2-ME. Nardi Júnior et al. (2012) evaluated 21 three- to eight-month old buffalo calves vaccinated with the B. abortus $\mathrm{B} 19$ vaccine and found that 270,300 and 360 days post-vaccination, the animals had no reactions in CFT, RBPT and 2-ME tests, respectively. Caporale et al. (2010) found that buffaloes vaccinated with the B19 vaccine were resistant to experimental infection with the strain 544 of B. abortus, 33 days post-vaccination. Pereira et al. (2015) vaccinated 36 three- to eight-month-old buffalo cows with the standard dose of the B19 vaccine, and at 390 days post-vaccination, $100 \%$ had no reaction on RBPT and 2-ME. These results show that the B19 vaccine provides effective immunization and is an important tool for the prevention of brucellosis in buffaloes.

There is no consensus in the literature regarding the efficiency of the RB51 vaccine in buffaloes. Fosgate et al. (2003) demonstrated that the vaccination of buffaloes with the RB51 strain does not protect against infection by $B$. abortus biovar 1. In addition, Diptee et al. (2007) showed that there is no effective protocol for the RB51 vaccine in buffaloes. Longo et al. (2009) identified B. abortus RB51 in milk samples, suggesting that this vaccine can be excreted in the milk of vaccinated adult buffalo cows. In contrast, Iovane et al. (2007) and Caporale et al. (2010) claimed that the RB51 vaccine in a dose three times greater than that recommended for cattle and a booster one month after the first inoculation offers protection against brucellosis in buffaloes. Given these conflicting results, it is clear that more studies with a larger number of animals are necessary to determine the efficacy of RB51 as a vaccine strategy.

The antibodies induced by the RB51 vaccine are not detectable using the conventional diagnostic techniques; therefore, specific diagnostic tools able to differentiate vaccinated from unvaccinated animals are necessary. The association of the RB51 brucellin skin test and RB51-CFT was evaluated by Tittarelli et al. (2015) in Italy, using 127 buffaloes, all negative according to RBPT and CFT, which were vaccinated with the RB51 vaccine. The authors observed that $84 \%$ of the animals showed positive reaction to the RB51-CFT and that $87 \%$ were positive on the RB51 brucellin skin test, 11 days post-inoculation. These results suggest the associated use of the RB51 brucellin skin test and RB51-CFT may be a reliable diagnostic tool to identify buffaloes vaccinated with the RB51 vaccine.

\section{CONCLUSIONS}

The lack of specific health control programs for buffaloes in Brazil and the different environmental conditions, especially in the Amazon biome, make it difficult to control brucellosis in these animals.

Vaccination of three- to eight-month-old females and the elimination of positive animals is still the best way to control the disease.

It is extremely important to take into consideration all differences in the epidemiology of brucellosis in cattle and buffaloes.

Further studies with buffaloes should be encouraged to develop and to implement efficient and specific control measures of brucellosis in this ruminant species.

\section{REFERENCES}

ABCB 2015. Associação Brasileira de Criadores de Búfalos. Raças. Available at <http://www.bufalo.com.br/racas.html> Accessed on 15 Dec. 2015.

Ackermann M.R., Cheville N.F. \& Deyoe B.L. 1988. Bovine ileal dome lymphoepithelial cell: endocytosis and transport of Brucella abortus strain 19. Vet. Pathol. 25(1):28-35.

Adesiyun A.A., Fosgate G.T., Persad A., Campbell M., Seebaransingh R. \& Stewart-Johnson A. 2010. Comparative study on responses of cattle and water buffalo (Bubalus bubalis) to experimental inoculation of Brucella abortus biovar 1 by the intraconjunctival route-a preliminary report. Trop. Anim. Health Prod. 42(8):1685-1694.

Adesiyun A.A., Fosgate G.T., Seebaransingh R., Brown G., Stoute S. \& Stewart-Johnson A. 2011. Virulence of Brucella abortus isolated from cattle and water buffalo. Trop. Anim. Health Prod. 43(1):13-16.

Akhtar S. \& Mirza M.A. 1995. Rates of seroconversion in the progeny of Brucella abortus seropositive and seronegative cattle and buffalo. Rev. Sci. Tech. 14(3):711-718.

Al Dahouk S., Tomaso H., Nöckler K., Neubauer H. \& Frangoulidis D. 2003. Laboratory-based diagnosis of brucellosis: a review of the literature. I. Techniques for direct detection and identification of Brucella spp. Clin. Lab. 49(9/10):487-505.

Bastianetto E., Amaral F.R., Carvalho L.B., Oliveira D.A.A. \& Leite R.C. 2005. Brucelose em rebanhos de búfalos criados na região do Alto São Francisco, Minas Gerais. Revta Bras. Reprod. Anim. 29(1):55-56.

Brasil 2006. Manual Técnico do Programa Nacional de Controle e Erradicação da Brucelose e Tuberculose (PNCEBT): legislação. Departamento de Defesa Animal, Secretaria de Defesa Agropecuária, Ministério da Agricultura, Pecuária e Abastecimento, Brasília, p.36-42.

Borghese A. \& Mazzi M. 2005. Buffalo Production and Research. FAO Regional Office for Europe, REU Technical Series. 67p. 
Borriello G., Peletto S., Lucibelli M.G., Acutis P.L., Ercolini D. \& Galiero G. 2013. Link between geographical origin and occurrence of Brucella abortus biovars in cow and water buffalo herds. Appl. Environ. Microbiol. 79(3):1039-1043.

Buddle M.B. 1956. Studies on Brucella ovis sp., a cause of genital disease of sheep in New Zealand and Australia. J. Hyg. 54(3):351-364.

Caitano M.A.B., Soares C.O., Ramos C.A.N., Ferraz A.L.J., Sanches C.C. \& Rosinha G.M.S. 2014. Detecção de Brucella abortus em tecidos bovinos utilizando ensaios de PCR e qPCR. Pesq. Vet. Bras. 34(6):497-502.

Caporale V., Bonfini B., Di Giannatale E., Di Provvido A., Forcella S., Giovannini A., Tittarelli M. \& Scacchia M. 2010. Efficacy of Brucella abortus vaccine strain RB51 compared to the reference vaccine Brucella abortus strain 19 in water buffalo. Vet. Ital. 46(1):13-19

Carmichael L.E. \& Bruner D.W. 1968. Characteristics of a newly recognized species of Brucella responsible for infectious canine abortions. Cornell Vet. 48(4):579-592.

Carvalho Neta A.V., Mol J.P., Xavier M.N., Paixão T.A., Lage A.P. \& Santos R.L. 2010. Pathogenesis of bovine brucellosis. Vet. J. 184(2):146-155.

Chaves N.P., Bezerra D.C., Santos L.S., Sá J.S., Santos H.P. \& Pereira H.M. 2012. Intercorrência entre leucose enzoótica e brucelose em búfalos (Bubalus bubalis) em sistema de produção extensivo. Pesq. Vet. Bras. 32(2):131-134.

Cheville N.F., Stevens M.G., Jensen A.E., Tatum F.M. \& Halling S.M. 1993. Immune responses and protection against infection and abortion in cattle experimentally vaccinated with mutant strains of Brucella abortus. Am. J. Vet. Res. 54(10):1591-1597.

Cockrill W.R. 1984. Water buffalo, p.52-62. In: Mason I.L. (Ed.), Evaluation of Domesticated Animals. Longman Group Ltd, Harlow, Essex, UK.

Corbel M.J. 1997. Brucellosis: an overview. Emerg. Infect. Dis. 3(2):213-221.

Costa E.O., Cury R. \& Rocha U.F. 1973. Sobre a ocorrência da brucelose em búfalos Bubalus bubalis (Lineaeus, 1958) no Estado de Goiás: inquérito sorológico. Biologicals 39:162-164.

Crasta O.R., Folkerts O., Fei Z., Mane S.P., Evans C., Martino-Catt S., Bricker B., Yu G., Du L. \& Sobral B.W. 2008. Genome sequence of Brucella abortus vaccine strain S19 compared to virulent strains yields candidate virulence genes. PLoS ONE 3(5):e2193

Di Giannatale E., De Massis F., Ancora M., Zilli K. \& Alessianti A. 2008. Typing of Brucella field strain isolated from livestock populations in Italy between 2001 and 2006. Vet. Ital. 44(2):383-388.

Diptee M.D., Asgarali Z., Campbell G., Fosgate G. \& Adesiyun A.A. 2007. Post-exposure serological and bacteriological responses of water buffalo (Bubalus bubalis) to Brucella abortus biovar 1 following vaccination with Brucella abortus strain RB51. Rev. Sci. Tech. OIE 26(3):669-678.

Erlich H.A., Gelfand D. \& Sninsky J.J. 1991. Recent advances in the polymerase chain reaction. Science 252(5013):1643-1651.

Enright F.M. 1990. The pathogenesis and pathobiology of Brucella infection in domestic animals, p.301-320. In: Nielsen K. \& Duncan R. (Eds), Animal Brucellosis. CRC Press, Boca Raton, Florida.

Evans A.C. 1950. Comments on the early history of human brucellosis, p.1-8. In: Larson C.H. \& Soule M.H. (Eds), Brucellosis. Waverly Press, Baltimore.

FAO/WHO 1986. Joint Food and Agriculture Organization/World Health Organization. Expert Committee on Brucellosis. World Health Organization Technical Report Series 740. World Health Organization, Geneva. Available at <http://apps.who.int/iris/handle/10665/40202> Accessed on 10 Jan. 2015.

FAO 1997. Animal Health Yearbook. Food and Agriculture Organization of the United Nations/International Office of Epizootics/World Health Organization, Rome.

Fosgate G.T., Adesiyun A.A., Hird D.W., Hietala S.K. \& Ryan J. 2002. Isolation of Brucella abortus biovar 1 from cattle and water buffaloes on Trinidad. Vet. Rec. 151(9):272-273.

Fosgate G.T., Adesiyun A.A., Hird D.W., Johnson W.O., Hietala S.K., Schurig G.G., Ryan J. \& Diptee M.D. 2003. Evaluation of brucellosis RB51 vaccine in domestic water buffalo (Bubalus bubalis) in Trinidad. Prev. Vet. Med. 58:211-215.
Fosgate G.T., Diptee M.D., Ramnanan A. \& Adesiyun A.A. 2011. Brucellosis in domestic water buffalo (Bubalus bubalis) of Trinidad and Tobago with comparative epidemiology to cattle. Trop. Anim. Health Prod. 43(8):1479-1486.

Foster G., Osterman B.S., Godfroid J., Jacques I. \& Cloeckaert A. 2007. Brucella ceti sp. Nov. and Brucella pinnipedialis sp. Nov. for Brucella strains with cetaceans and seals as their preferred hosts. Int. J. Syst. Evol. Microbiol. 57(11):2688-2693.

Garofolo G., Foster J.T., Drees K., Zilli K., Platone I., Ancora M., Cammà C., De Massis F., Calistri P. \& Di Giannatale E. 2015. Genome sequences of 11 Brucella abortus isolates from persistently infected Italian Regions. Genome Announc. 3(6):e01402-e01415.

Garcia-Carrillo C. 1990. Animal and human brucellosis in the Americas. Office International dês Épizooties, Paris.

Gentile A. 1957. Brucellosis in buffaloes. Vet. Ital. 8:591-596.

Guarino A., Fusco G., Serpe L., Gallo P., Di Matteo A., Urbani G., Tittarelli M., Di Ventura M. \& Condoleo R. 2001. Indirect ELISA for diagnosis of brucellosis in water buffaloes (Bubalus bubalis) in Italy. Vet. Rec. 149(2):88-90.

Hinić V., Brodard I., Thomann A., Holub M., Miserez R. \& Abril C. 2009. IS711-based real-time PCR assay as a tool for detection of Brucella spp. in wild boars and comparison with bacterial isolation and serology. BMC Vet. Res. 5(22):1-8.

Harmon B.G., Adams L.G. \& Frey M. 1988. Survival of rough and smooth strains of Brucella abortus in bovine mammary gland macrophages. Am. J. Vet. Res. 49(7):1092-1097.

Huddleson I.F. 1931. Differentiation of the species of the genus Brucella. Am. J. Public Health Nations Health 21(5):491-498.

IBGE 2014. Produção da Pecuária Municipal. Instituto Brasileiro de Geografia e Estatística. <Disponível em <http://www.ibge.gov.br/home/estatistica/economia/ppm/2011/default_pdf.shtm> Acesso em 29 out. 2015.

Iovane G., Martucciello A., Astarita S., Galiero G., Pasquali P., Adone R., Ciuchini F., Pagnini U., Guarino A. \& Fusco G. 2007. Vaccino Brucella abortus RB51: primi risultati sull'innocuità ed attività immunogena nella bufala mediterranea. Progres. Vet. 62(1):19-21.

Jamal S.M., Afzal M. \& Ahmed S. 2003. The immune response of guinea pigs and buffalo calves to the locally prepared Brucella abortus strain 19 vaccine. Rev. Sci. Tech. 22(3):893-897.

Jorge A.M. 2005. Produção de carne bubalina. Revta Bras. Reprod. Anim. 29(2):84-95.

Konrad J.L., Campero L.M., Caspe G.S., Brithuega B., Draghi G., Moore D.P., Crudeli G.A., Venturini M.C. \& Campero L.M. 2013. Detection of antibodies against Brucella abortus, Leptospira spp., and Apicomplexa protozoa in water buffaloes in the Northeast of Argentina. Trop. Anim. Health Prod. 45(8):1751-1756.

Kumar M. \& Chand P. 2011. Improvement in the diagnosis of Brucella abortus infections in naturally infected water buffaloes (Bubalus bubalis) using an ELISA with a Protein-G-based indicator system. Trop. Anim. Health Prod. 43(8):1493-1499.

Láu H.D. \& Singh N.P. 1985. Distribuição e prevalência da brucelose em búfalos no estado do Pará. Bolm Pesq., Embrapa-CPATU. Available at <http:// www.infoteca.cnptia.embrapa.br/handle/doc/380966> Accessed on 20 Jan. 2016.

Longo M., Malardo K., Montagnaro S., De Martino L., Gallo S., Fusco G., Galiero G., Guarino A., Pagnini U. \& Iovane G. 2009. Shedding of Brucella abortus rough mutant strain RB51 in milk of water buffalo (Bubalus bubalis). Prev. Vet. Med. 90(1/2):113-118.

Martínez D., Thompson C., Draghi G., Canavesio V., Jacobo R., Zimmer P., Elena S., Nicola A.M. \& de Echaide S.T. 2014. Pheno- and genotyping of Brucella abortus biovar 5 isolated from a water buffalo (Bubalus bubalis) fetus: first case reported in the Americas. Vet. Microbiol. 173(1/2):172-176.

Mathias L.A., Chaves L.F., Girio R.J.S. \& Del Fava C. 1998. Avaliação de um teste imunoenzimático competitivo no diagnóstico sorológico da brucelose em búfalos (Bubalus bubalis). Pesq. Vet. Bras. 18(3/4):111-114.

Meador V.P. \& Deyoe B.L. 1989. Intracellular localization of Brucella abortus in bovine placenta. Vet. Pathol. 26(6):513-515. 
Megid J., Albert D., Fagliari J.J., Paes A.C., Listoni F.P., Pinto M.R., Ribeiro M.G., Thiébaud M., Ueno T. \& Garin-Bastuji B. 2005. Isolation of Brucella abortus from cattle and water buffalo in Brazil. Vet. Rec. 156(5):147-148.

Menshawy A.M.S., Perez-Sancho M., Garcia-Seco T., Hosein H.I., García N., Martinez I., Sayour A.E., Goyache J., Azzam R.A.A., Dominguez L. \& Alvarez J. 2014. Assessment of genetic diversity of zoonotic Brucella spp. recovered from livestock in Egypt using Multiple Locus VNTR Analysis. BioMed Res. Int. 2014:1-7.

Mohan R.N. 1968. Diseases and parasites of buffaloes. Vet. Bull. 38(10): 647-659.

Molnár L., Molnár E., Lima E.S.C. \& Dias H.L.T. 2002. Avaliação de seis testes sorológicos no diagnóstico da brucelose bubalina. Pesq. Vet. Bras. 22(2):41-44.

Montagnaro S., Longo M., Mallardo K., Pisanelli G., De Martino L., Fusco G., Baldi L., Pagnini U. \& Iovane G. 2008. Evaluation of a fluorescence polarization assay for the detection of serum antibodies to Brucella abortus in water buffalo (Bubalus bubalis). Vet. Immunol. Immunopathol. 125(1/2):135-142.

Moreno E., Cloeckkaert A. \& Moriyón I. 2002. Brucella evolution and taxonomy. Vet. Microbiol. 90(1/4):209-227.

Nardi Júnior G., Ribeiro M.G., Jorge A.M., Megid J. \& Silva L.M. 2012. Serological profile of buffalo (Bubalus bubalis) female calves vaccinated with standard Brucella abortus strain 19 vaccine uring rose bengal, 2-mercaptoethanol and complement fixation tests. Biologicals 40(2):158-161.

Nasir A.A., Parveen Z., Shah M.A. \& Rashid M. 2004. Seroprevalence of brucellosis in animals at government and private livestock farms in Punjab. Pakistan Vet. J. 24(3):144-146.

Nicoletti P. 1980. The epidemiology of bovine brucellosis. Adv. Vet. Sci. Comp. Med. 24:69-95.

Nicoletti P. 1990. Vaccination against Brucella. Adv. Biotechnol. Processes 13:147-168

Nielsen K., Gall D., Smith P., Kelly W., Yeo J., Kenny K., Heneghan T., McNamara S., Maher P., O'Connor J., Walsh B., Carroll J., Rojas F., Perez B., Wulff O., Buffoni L., Salustio E., Gregoret R., Samartino L., Dajer A. \& Luna-Martinez E. 2001. Fluorescence polarization assay for the diagnosis of bovine brucellosis: adaptation to field use. Vet. Microbiol. 80(2):163170.

Nielsen K., Smith P., Widdison J., Gall D., Kelly L., Kelly W. \& Nicolletti P. 2004. Serological relationship between cattle exposed to Brucella abortus, Yersinia enterocolitica 0:9 and Escherichia coli 0157:H7. Vet. Microbiol. 100(1/2):25-30.

Ogassawara S., Cury R., D’apice V.B., Mendes M.F.M. \& Rocha U.F. 1969. Higroma articular brucélico em búfalo, Bubalus bubalis (Linneu, 1758). Arqs Inst. Biológico São Paulo 36:117-121.

Osterman B. \& Moriyon I. 2006. International Committee on Systematics of Prokaryotes Subcommittee on the taxonomy of Brucella. Int. J. Syst. Evolut. Microbiol. 56:1173-1175.

Pacheco G. \& Mello M.T. 1956. Brucelose. Livraria Ateneu, Rio de Janeiro. 727p.

Paulin L.M.S., Samartino L.E., Conde S.B., Federsoni I.S.P., Ferreira F., Amaku M. \& Ferreira Neto J.S. 2012. Fluorescence polarization assay, competitive enzyme-linked immunosorbent assay (ELISA-C) and indirect ELISA for the diagnosis of brucellosis in buffaloes (Bubalus bubalis). Ciência Rural 42(9):1621-1626.

Pereira A.P.M., Casseb A.R., Casseb L.M.N., Vale W.G. \& Pereira W.L.A. 2015. Humoral immune response of buffalo heifers (Bubalus bubalis) vaccinated with B19 strain of Brucella abortus. Arch. Vet. Sci. 20(1):56-61.

Polding J.B. 1947. Brucellosis in India. Indian J. Vet. Sci. Anim. Husb. 17:147-155

Ramnanan A., Diptee M., Asgarali Z., Campbell M. \& Adesiyun A.A. 2012. Serological and bacteriological responses of water buffalo (Bubalus bubalis) vaccinated with two doses of Brucella abortus strain RB51 vaccine. Trop. Anim. Health Prod. 44(7):1451-1458.

Rankin J.E.F. 1965. Brucella abortus in bull: a study of twelve naturally-infected cases. Vet. Rec. 77:132-135.

Renukaradhya G.J., Isloor S. \& Rajasekhar M. 2002. Epidemiology, zoonotic aspects, vaccination and control/eradication of brucellosis in India. Vet. Microbiol. 90(1/4):183-195.
Samartino L.E. \& Enright F.M. 1996. Brucella abortus differs in the multiplication with in bovine chorioallantoic membrane explants from early and late gestation. Comp. Immunol. Microbiol. Infect. Dis. 19(1):55-63.

Sandoval L.A., De Arruda N.M., Teruya J.M., Giorgi W., Amaral L.B.S. \& Mazanti M.T. 1979. Pesquisas em bubalinos: prevalência da brucelose e leptospirose no Estado de São Paulo, Brazil. Arqs Inst. Biológico São Paulo 45(11):209-212.

Santa Rosa C.A. \& Castro A.F.P. 1969. Títulos aglutinantes para "Brucella" em búfalos do Estado de São Paulo. Arqs Inst. Biológico São Paulo 28:3539.

Sellem M.N., Boyle S.M. \& Sriranganathan N. 2010. Brucellosis: a re-emerging zoonosis. Vet. Microbiol. 140(3/4):392-398.

Scholz H.C., Hubalek Z., Sedlácek I., Vergnaud G., Tomaso H., Al Dahouk S., Melzer F., Kämpfer P., Neubauer H., Cloeckkaert A., Maquart M., Zygmunt M.S., Whatmore A.M., Falsen E., Bahn P., Göllner C., Pfeffer M., Huber B., Busse H.J. \& Nöckler K. 2008. Brucella microti sp. nov., isolated from the common vole Microtus arvalis. Int. J. Syst. Evol. Microbiol. 58(2):375382.

Scholz H.C., Hofer E., Vergnaud G., Le Fleche P., Whatmore A.M., Al Dahouk S., Pfeffer M., Krüger M., Cloeckaert A. \& Tomaso H. 2009. Isolation of Brucella microti from mandibular lymph nodes of red foxes, Vulpes vulpes, in lower Austria. Vector Borne Zoonotic Dis. 9(2):153-156.

Scholz H.C., Nöckler K., Göllner C., Bahn P., Vergnaud G., Tomaso H., Al Dahouk S., Kämpfer P., Cloeckaert A., Maquart M., Zygmunt M.S., Whatmore A.M., Pfeffer M., Huber B., Busse H.J. \& De B.K. 2010. Brucella inopinata sp. Nov., isolated from a breast implant infection. Int. J. Syst. Evol. Microbiol. 60(4):801-808.

Silva J.B., Fonseca A.H. \& Barbosa J.D. 2014a. Serological survey of $M y-$ cobacterium bovis, Brucella abortus and Borrelia burgdorferi in water buffaloes in the northern region of Brazil. Revta Salud Anim. 36(1):3539.

Silva J.B., Rangel C.P., Fonseca A.H., Morais E., Vinhote W.M., Lima D.H.S., Silva N.S. \& Barbosa J.D. 2014b. Serological survey and risk factors for brucellosis in water buffaloes in the state of Pará, Brazil. Trop. Anim. Health Prod. 46(2):385-389.

Sousa M.G.S., Salvarani F.M., Bomjardim H.A., Fonseca Júnior A.A., Preis I.S., Brito M.F., Leite R.C. \& Barbosa J.D. 2015a. Infecção transplacentária e intrauterina por Brucella abortus em búfalos (Bubalus bubalis). Pesq. Vet. Bras. 35(11):882-888.

Sousa M.G.S., Brito M.F., Ubiali D.G., Fonseca Júnior A.A., Silva J.B., Belo Reis A.S., Oliveira C.M.C. \& Barbosa J.D. 2015b. Detecção de Brucella abortus em linfonodos de búfalas (Bubalus bubalis) em diferentes fases da gestação. Pesq. Vet. Bras. 35(12):951-955.

Stoenner H.G. \& Lackman D.B. 1957. A new species of Brucella isolated from the desert wood rat Neotoma lepida Thomas. Am. J. Vet. Res. 18(69):947-951.

Tittarelli M., Atzeni M., Calistri P., Di Giannatale E., Ferri N., Marchi E., Martucciello A. \& De Massis F. 2015. A diagnostic protocol to identify water buffaloes (Bubalus bubalis) vaccinated with Brucella abortus strain RB51 vaccine. Vet. Ital. 51(2):99-105.

Vassallo D.J. 1992. The corps disease: brucellosis and its historical association with the Royal Army Medical Corps. J. R. Army Med. Corps. 138(3):140-150.

Whatmore A.M., Davison N., Cloeckaert A., Al Dahouk S., Zygmunt M.S., Brew S.D., Perret L.L., Koylass M.S., Vergnaud G., Quance C., Scholz H.C., Dick Júnior E.J., Hubbard G. \& Schlabritz-Loutsevitch N.E. 2014. Brucella papionis sp. Nov., isolated from baboons (Papio spp.). Int. J. Syst. Evol. Microbiol. 64(12):4120-4128.

Wilesmith J.W. 1978. The persistence of Brucella abortus in calves: a retrospective study of heavily infected herds. Vet. Rec. 103(8):149-153.

Wray C. 1975. Survival and spread of pathogenic bacteria of veterinary importance within the environment. Vet. Bull. 45:543-550.

Xavier M.N., Paixão T.A., Poester F.P., Lage A.P. \& Santos R.L. 2009. Pathology, immunohistochemistry and bacteriology of tissues and milk of cows and fetuses experimentally infected with Brucella abortus. J. Comp. Pathol. 140(2/3):149-157. 